\title{
Short Story Development of Der Gegenwart Prosa For German Drama Manuscript Using Adjacency Pair Model: (Social Science and Humaniora)
}

\author{
Ahmad Bengar Harahap ${ }^{1}$ \\ \{mattbeng1@gmail.com\} \\ Universitas Negeri Medan, Indonesia ${ }^{1}$
}

\begin{abstract}
Drama is a part of literary work that can be staged through the drama staging process using the main elements of the script and play, in addition to the other supporting elements. The text is different from the role playing. The manuscript is a sequence of stories before being staged. That sequence in modern drama is in the form of writing using conversation or dialogue models to be performed. The perceptual model can be used by using a Adjacency Pair Model in the German drama as well. These conversation models were initially needed in the role playing as the basis for determining the play. This play comes from the concept of making conversations or dialogues from a play. Good German drama scripts certainly use dialogue or good German conversation. Manuscripts are said to be good if there are conflicts, emotives, and behavioral images that are able to provide new inspiration for those who apply the text. The drama script was done by the script writer while the play was done by the director. The manuscript or play cannot be separated from the conversation or dialogue model built by the writer or director. Varieties and styles are usually in the form of comedy, tragedy, repertoire and parody. Then based on the length of the short conversation or dialogue a drama depends on the round of the drama. All of that certainly has an effect on the form of the drama that was made for it. This research was conducted at the German Language Program of UNIMED to analyze the ability of students to write German drama scripts in designing dialogues or conversations using Adjacency Pair Model..
\end{abstract}

Keywords: German Drama Manuscript, Adjacency Pair Model.

\section{$1 \quad$ Introduction}

Drama is one of the literary works which uses the language as a conversation or dialogue which has aesthetic words. In essence, the aesthetics of these words are the core of the drama's text into conversations or dialogs which contain conflicts (contradictions). These conflicts are arranged so that they form a plot and are expressed in the form of dialogue. How to determine conflict and how to write drama scripts? To write drama literary works, you can start by defining conflicts, arranging sequences of events in one round, developing the sequence of events into one round drama scripts, completing dialogues, commenting on and editing drama plays. To identify conflicts can be done based on events in literary prose, such as novels, novels, short stories, etc. In writing German drama scripts as a foreign language, the competence of language and knowledge of German is important for a scriptwriter to be able to compile the Sequence of Events for One Round in a German drama. Drama manuscripts can 
be obtained from the writer's imagination or derived from literary works in the form of prose or stories such as the German short story (Kurzgeschichte). One of the competencies that must be possessed by the playwright is the ability to write drama scripts to be prepared in terms of (1) the suitability of the dialogue with the events to be described, (2) the clarity of the language in the dialogue, (3) the accuracy of the form of the drama, and (4) the clarity of the narrative (explanation) so that it is easily staged. Then it is only possible to compile a drama script with a series of events that have been determined based on the source of the event or also from the story telling by considering in terms of (1) the uniqueness of the conflict raised in the drama script, (2) the resolution of conflict resolution, (3) the suitability of the dialogue with the series of events described, (4) clarity of the contents of the dialogue, and (5) clarity of the narrative (explanation) so that it is easily staged. To write dialogues or conversations that are appropriateand appropriate to the events in a drama script can be used the corresponding pair model. Because the pair model corresponds, its elaboration is more complex and detailed about the types, characteristics, and functions of each unit and its parts. For example, the structure of preference, order and silence. By analyzing this paired model, the competence and meaning of the conversation of a language and the interaction of language are more fully understood. As for the language in question is not only Indonesian or regional languages, but also foreign languages outside the mother tongue of speakers can be analyzed in the corresponding pairing model that occurs in the structure of the conversation in the drama script. Based on the background above, this study was conducted to observe and analyze the ability to write German drama scripts by using a pair pair model derived from German modern prose (Prosa der Gegenwart) as the subject of the Literature course in the German language program at Unimed. Therefore, this research is very important to be carried out as an effort to increase learning motivation and improve competence in subjects or fields of general German language and German Literature or Literature.

\section{Literature Review}

\subsection{Definition Of Drama}

Manuscripts In an internet web source it is stated that drama is often equated with theater. These two terms indeed overlap. Drama comes from the Greek "draomai" which means to do, act; while theater comes from the Greek word also "theatron" means the place of the show. The word theater itself refers to a number of things, namely: drama, performance building, stage performance, group of drama players, and all performances shown. Even so in a simple way, as stated by JakobSoemardjo, the drama is divided into two, the first is the drama script and the second is the drama drama. This second term, the stage drama, is equated with theater.

Literary work in the form of dialogues and possible to be performed as a spectacle is called drama, while works of art in the form of performances whose elements consist of motion art, music, decoration, make up, costum, and others are called theater. Drama includes literary art. Theater is a performance art. In addition to these two terms, there are other similar terms namely plays and tonils. The play comes from the Javanese language and tonil comes from the Dutch language. The drama script has its building elements. According to Herman J. Waluyo, drama builds on physical structure and inner structure. The physical structure of the drama is:

(1) plot;

(2) characterization / characterization; 
(3) dialogue;

(4) background;

(5) side text (technical instructions).

While the inner structure of drama is: (1) theme, (2) mandate. Theater as a performing art has the following elements: (1) actor and casting, (2) director, (3) stage organizer (consisting of: stage / stage arrangement, decoration / scenary, lighting / lighting, and sound management / soundsystem), (4) artistic stylist (consisting of: makeup / make up, dress / costum, music and sound effects / music and soud effect), (5) script, (6) producer, (7) the audience.

\subsection{Techniques for Writing Drama Scripts}

Drama or drama writing techniques have specificities when compared to poetry or prose writing techniques. Because it has the possibility to be staged, the drama script has side text and main dialog. Side text or technical instructions are very useful for the director to get around the performance. The director who is obedient to the script, will follow all instructions written in the side text. On the other hand there is also a director who is not obedient to the side text because he is intentionally interpreting the drama text loosely. Thus, the side text (and also the dialogues) can be compatible or can be different if performed in the form of performances. The director's role is very important in addressing the drama script. The technique or method of writing the Drama Text itself has different writing techniques. Manuscripts that are able to provide creative inspiration are certainly manuscripts that have complete drama elements rather than short texts. Next, in the drama script, dialogue and stage direction information, it greatly helps the development of characters, plots, and themes. In addition, both can provide input for the determination of the play (staging) performed by the director. Dialogue is a reciprocal statement on the basis of the stimulus and response that arises and the perpetrators. Whereas the behavior statement refers to an order that tells the offender to do things that are outward. In the drama script, behavior information often starts the dialogue, explains the behavior of dialog, and is printed in parentheses. Dialogue and behavior information relate and complement each other according to the source of the story or event that has been determined.

\subsection{Adjacency Pair Model}

\subsubsection{General Understanding}

Nature and Model or Section Cook (1997) suggests Adjacency Pair is a pair of discourse moves that often together, e. G. question and answer (matching pairs are pairs of forms of oral language events that are always together, such as questions and answers). A stimulus with the answer is the corresponding pair spoken by the speaker and the listener at the beginning of communication, in the middle, or in the end. This corresponding pair is an important unit in communication even though it seems very simple and concise (Lubis, 1996: 109). And Yule (2006: 132-134) explains that what is called an adjacency pair is an automatic order in the structure of the conversation, such as greetings and high congratulations. In German, for example, as follows:

1. Anna: Hello (Hello) 
Bill: $\mathrm{Hi}(\mathrm{Hi})$

2. Anna: WieGehts? (How are you?)

Bill: Gut, Danke (Fine, thank you)

3. Anna: Auf Wiedersehen! (See you later !)

Bill: Tschüs (Goodbye)

These pairs consist of the first part and the second part is spoken by two different speakers. The first part of the speech quickly created the hope of speaking the second part of his partner. Failure to produce speech for the second answer is considered to be a significant vacuum and therefore, this void is meaningful. There are substantial form variations that are used to fill the gap in the corresponding pair. Therefore the corresponding pair must always have two parts, the first and the second. In particular, there are many sequences in a conversation, such as a question-and-answer sequence, answers to thanks, requests, and others.

Saragih (2006: 27) explains that conversations are generally constructed by utterances in pairs or two parts. For example, the following conversation consists of two parts.

A: "Want the first flight"? (first part)

B: "Good. I take it ". (The second part).

Between these two parts there can be an insert, as in the following example:

A: "Want the first flight"? (Q1 - first question)

B: "What time?" (Q2-second question)

A: "Seven" (A2 second answer)

B: "Good. I took that ". (A1- first answer)

The corresponding pairing model can also be done by isolating it into the smallest units so as to produce pairs side by side. For example answer questions, greetings, bargains. Coulthard (in Purba, 2002: 108) gives the pair the same as the unit of conversation structure. Therefore, when a speaker produces a speech as the first part and the other person is expected to provide a harmonious item in the second part. Coulthard divides the corresponding pair into eight models / types, namely

1. Greetings, examples
A: "Hello"
B: "Hi"

2. Call-Answer, example

$$
\begin{aligned}
& \text { A: "Jimmy!" } \\
& \text { B: "Yes, ma'am". }
\end{aligned}
$$

3. Complaint-Complaint, example

A: "You let the tap open".

B: "Not me".

4. Apologies, examples

A: "It's already 9:00 a.m."

B: "Sorry, I'm late".

5. Request-Welcome, example

A: "Can you add more coffee?"

B: "Of course, please take it yourself".

6. Requests for Information-Giving, examples

A: "What time is it?" 
B: "5 o'clock right".

7. Offer-Acceptance, example

A: "Want to ride?"

B: "You saved me".

8. Offer-Rejection, example

A: "Please, cigarette."

B: "I don't smoke, thank you".

There is another opinion that gives an understanding of the corresponding pair and its parts. For example, Jefferson (2006) on an internet site revealed that the so-called matching pairs are conversions that are grouped in a place by acts of paired words. Example

1. Greetings (Greeting-Greeting);

2. Proposal-Acceptance;

3. Summons of Acknowledgment;

4. Complaints (Accusation-Denial);

5. Promise-Acceptance;

6. Receipts (Compliment-Acceptance);

7. Compliment-Rejection;

8. Request for Information-Rejection (Request for Information-Refusal);

9. Request for Information-Grant Request.

In a pair, such as summons-acknowledgment, the claim is called the first part or part of the first pair (first pair-part / FPP) while recognition is referred to as the second part or part of the second pair (second pair-part / SPP).

FPP forms a conditional relationship (conditional relevance) which provides possibilities for answers (responses) that form SPP. Examples in English and German:

1. a: Hello (Hello)

b: Hi / Hello (Hey / Hello) $\rightarrow$ (greetings)

2. a. How are you? (Wiegeht's?)

b. Fine, thanks. (Gut / Prima, Danke) $\rightarrow$ (questions / answers / question-answer)

Goldkuhl divides the corresponding pair in the form of:

1. Questions - Answers (Question - Answer)

2. Greetings - Greetings (Greeting - Greeting)

3. Offer - Acceptance (Offer - Acceptance)

4. Request - Offer (Request - Acceptance)

5. Complaints - Complaint - Excuse

\subsubsection{Function and Distribution}

The pair function corresponds as follows:

1. As an opening and closing a conversation;

2. As steps (moves) in a conversation;

3. The first part in the corresponding pair functions as the next speaker selecter; 
4. The corresponding pair can be used as a remedial exchange namely exchange or change from the previous section;

5. The components in the corresponding pair can be used to form a longer conversation relationship. Distribution rules for matching pairs in conversations are defined as follows:

a. The second part always appears after the first part.

b. The first part can appear in anything in the conversation unless the first first part appears directly called insertion.

\subsection{Writing plays as a Learning Development}

Model The learning development model is very diverse. The diversity of development models can lead to different approaches from each model. Researchers can choose one of the development models for research. Rahman (2013: 198-219) explains that there are several learning models that can be used such as Kemp, Dick \& Carey, ADDIE Models, and 4-D Models. In this study, the ADDIE model will be used. The ADDIE (Analysis-DesignDevelopment-Implement-Evaluate) model appeared in the year 1990s developed by Reiser and Mollenda. The ADDIE function is to design and develop an effective and efficient training. The stages contained in the ADDIE model consist of: analysis, design, development, implementation, and evaluation. The advantage of the ADDIE model is that this model is simple and easy to learn and a systematic structure. This ADDIE model consists of 5 components that are interrelated and systematically structured, which means that from the first stage to the fifth step, the application must be systematic, it cannot be sorted randomly or we can choose which one we think we want to prioritize. Because these five stages / steps are very simple compared to other design models. Whereas the shortage of the ADDIE model is that in the analysis phase it takes quite a long time to divide the analysis into two, namely performance analysis and needs analysis. (http://www.academia.edu 5152425 / Papers_model_ADDIE, 4 April 2016 21.05)

\section{Results And Discussion}

In this section the data used are 3 German prose in the form of short stories (short stories) taken from the book "Prosa der Gegenwart" which is used as a model or example in learning "Literature" or Literature courses in the German language education program Unimed. In accordance with the steps of the ADDIE model used in the design of this study, it was carried out in stages as described below.

1. Descriptive Analysis The steps taken in this phase are analyzing the description of contents and text from Prose der Gegenwart. This performance analysis step is knowing the structure of German prose. In this step the structure and description of the contents of the prose text is done by delving into the intrinsic and extrinsic elements of the prose first. In general, experts divide the imaginary prose intrinsic elements of plot, character, character, characterization, setting, point of view, style of language, message, and theme. There is another element, namely the storytelling style (Siswanto, 2008: 142).

2. Design In this phase the initial design will be designed in the form of the corresponding pair model in each paragraph. Based on the structure or description of the prose contents in the form of intrinsic and extrinsic interpretations that have been described above, 
corresponding pairs are arranged again according to the nature, function and distribution that may arise from each paragraph or multiparagrap. Then it can be arranged the model or part of the corresponding pair from this prose into the material of the drama script.

3. Development (Development) In this phase, the initial design that was completed earlier, it will be developed into a drama script which contains dialogues adapted to the first phase

4. Implementation In this phase, the prose that has been arranged with this paired pairing model will be applied in literary learning and then practiced into drama using drama scripts that have been created using the appropriate matching pair model.

5. Evaluation In this phase a questionnaire will be given, to find out whether the media that is made is useful and interesting and is appropriate with the ajasensi model. If there are still shortcomings, revisions and improvements will be needed. The questionnaire will be given to literary experts and German-speaking experts from native speakers.

\subsection{Results of Development}

Title of Prosa: Der Kaufmann und das Mädchen By: Angela Sommer

a. Analysis of intrinsic and extrinsic elements

1. Intrinsic Elements After reading and analyzing, there are some intrinsic elements of this prose:

a. Theme: Rich Merchant and Binal Girl

b. Mandate:: - Do not be too easy to trust others that we don't know yet. - Don't be too complacent with female beauty.

c. Ejambemen: Coherence

d. Language: German

e. Language style: Non Formal (colloquial)

f. Majas: Hyperbole h. Neveaux: Human

g. Plot / Flow: Forward backwards

h. Settings: In the Car in the afternoon, in front of the theater cashier, in the theater hall, in the theater 14 , and in the lobby.

i. Statement:

1) Der Kaufmann: Friendly, wishy-washy, as is.

2) Das Mädchen: Flirtatious and indifferent.

3) Rolf: Firm.

4) Die andere Frau: Good and Friendly.

5) Die Alte Frau: Fierce and chatty.

6) Der Mann: Cunning and evil.

7) Die hältendeFrautür: Flirty and friendly.

2. Extrinsic Elements: After reading the extrinsic element found in this prose in the form of any values contained in the contents of the story, as follows : a. Sociological Value: Der Kaufmann entered the trap das Mädchen. b. Moral Value: Must be polite and as a woman must be able to control herself. c. Value of Truth: You cannot cheat to enter the theater.

3. Prose Text Title: Der Kaufmann und das Mädchen Author: Angela Sommer

4. Play scriptFollowing are the results of the drama script produced using the following pair model 
Früherblebte den reichen Mann in einekleienStadt.Er hat viel Geld schönesHaus und viele Autos. In einen Tag ladeteterseinen Freund anschauenfahren. Aber in Theater Träffernichtseinen Freund sondernTraffmiteinemmystoriösenMädchen. Am ende das Mädchenließ den Mann. Und der Mann suchte die Frau Verrücktesteverrücktbistjetzt.

\section{(Im Auto fahrtgerade)}

Der Kaufmann :Du dududu...

Ichmöchtesehr das Theater anschauen.Aber

Request of Information

... mitwem? Aha Rolf. Rolf,wobist du? $\longrightarrow$ Acceptance

Rolf :Hallo, was....zuHause.Warum?

Der Kaufmann : Möchtest du jetztanschauen?

Ich bin sehrmüde. Und auchmöchtemichmitdiretwassagen.

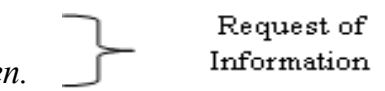

\begin{tabular}{|c|c|c|c|}
\hline Rolf & $\therefore$ Jetzt?? $\longrightarrow$ & Delay of Information & Acceptance and requst \\
\hline Der Kaufmann & $\therefore J a . \longrightarrow$ & Request & Information \\
\hline Rolf & $\begin{array}{l}\text { : Jetztkannichni } \\
\text { Und was möcht }\end{array}$ & $\begin{array}{l}\text { t. wieistheuteAbend? } \\
\text { t du sagen? }\end{array}$ & \\
\hline $\begin{array}{l}\text { Der Kaufmann } \\
\text { Oke, späterbricl }\end{array}$ & $\therefore$ Hmmm... etwa & (hahaha) & \\
\hline
\end{tabular}

(Im Theater treffsich Rolf)

Die alte Frau

Der Kaufmann

: Kannichihnenhelfen?

: O... ja, hast du schoneinen Mann hiergewartengesehen?

Die alte Frau

: (Lachen) hiervieleMännemwollen Theater

anschauen von demalten, jungen, großen,

kleinen Mann. Ichfinde, esgehtnicht so wieihnenzusuchen.

Der Kaufmann

: Oh...Ok. Dankeschön.

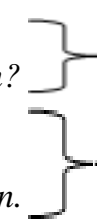

Acceptance-

Request.

Request

Die alte Frau

: Siewollentreten, oder nein? Das Theater möchtetschon

beginnen. $\longrightarrow$ Request

Der Kaufmann

Die alte Frau

Der Kaufmann

Die alte Frau

: Später, ichhabeschondem das Ticket gehabt.

: Entschuldigung. Das kannnicht.

: Warum? Ichhabeschönheutereserviert.

: Kannnicht. (Böse) du denkstmichdumm?

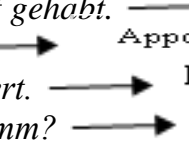

Request of Information ppolgize

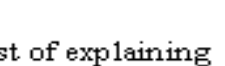

Ichhabeschonlangehiergearbeitet. Verstanden.

Der Kaufmann

Die alte Frau

: Aber... (verwirrt)

: gehdraußen.

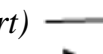

(Im foyer triffeinenschlechten Mann)

Der Mann

: (rauchengerade)

Kannnichtanschauen?

Hei, Warumbist $d u$

traurigbro?

Der Kaufmann

: Ja, hmm... hast du schonmeinen Freund gesehen?

Der Mann

Er hat geradehin und züruckhier.

Acceptance

Ichhabe das Ticket, aberpaulmöchteichtreten.

Willst du mein Ticket bezahlen?

Der Kaufmann

: Nein, Ichsehenicht.

Requst of

Information

Der Mann

$\therefore$ Ja, will, abermöchteichmitmeinem Freund.

: Selbstistheftig. Glauhanmich Daг Zimmer ist 14.7 Reihe.

Repeat 
Der Kaufman

Der Mann

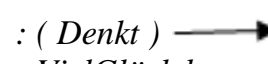

(In der Theater Tür 14)

Die Frau Türhaltend : MöchtenSie herein? $\longrightarrow$ Request

Der Kaufmann $\quad: H m m \ldots J a \longrightarrow \quad$ Acceptancde

Die Frau Türhaltend : TretenSiebitte, dortgibtes so viele Menschen.

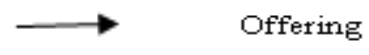

Plözlichkömmt das schönesMädchen

$\begin{array}{ll}\text { Das Mädchen } & : \text { Bevor herein korrigier Ticket. } \longrightarrow \\ \text { Der Kaufmann } & : \text { ich bin mi dir. Dieses Ticket }(\text { Umarmon) } \\ \text { Die Frau Türhaltend }: \text { Okay, Danke. Herein bitte. } \longrightarrow & \text { Request }\end{array}$

Das Mädchen : (drückt der Kaufmann an die Wand)

Der Kaufmann $\quad$ :Danke. (Nervös und umarmung)

: Seinichtzudanken, entspannt, bist du arm? $\longrightarrow$ Request2

Der Kaufmann

Das Mädchen

: ( erschrocken ) Darfichetwas bitten?

: Was? Sagst du Umarmen, Küssenodermehr?

Der Kaufmann

: ( schloß die Augen )

)

$\rightarrow$ Request and asking

Plötzlich der Kaufmann istschonausserhalb des Theaters.

Die andere Frau : Was machst du hier? Gehbitte! Das Theater wollen $\longrightarrow$ Request.

Der Kaufmann : (erschrocken). Warumsehrdunkel? Und warum bin ichhier?

Woist das Mädchen?

Der Kaufmann

Die andere Frau

Der Kaufmann

Die andere Frau

Der Kaufmann

Die andere Frau

: (verwirrt) ichhabeschondenn das Theater dieserPlatzgesehen.

Denied

$\therefore$ (Lachen $) \longrightarrow$ Asking

: Warum??? Ich bin Falsch die Platz? Oder dieUhr? $\longrightarrow$ Request

: Nein, du bistrichtig.

: So, siehstdu. Das schönesMädchen? : kommmit. ( außerhalb)

Die Frau? $\longrightarrow$ Request

Der Kaufmann :Ja, ja, warumbist du hier? Was möchst du?

Das Mädchen : Entshuldigung, ichkannnichtlangehierzuubrigens.

Ichwerdeschongewartet.

Der Kaufmann

Der Kaufmann

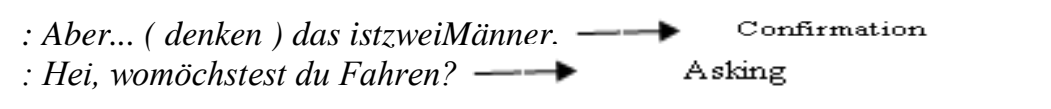

\section{Conclusions}

From the results and discussion of the research above it can be concluded that:

1. Using the ADDIE model in the process of developing Prosa der Gegenwart short stories into drama script using the corresponding pair model, the results of the research are obtained in the form of:

a. The right analysis is in the form of descriptive analysis that describes the overall prose interpretation in the form of intrinsic, extrinsic, and short story synopsis. 
b. The design of the study was carried out with a matching pair model that was dominated by the Information and Information Giving Request model, and several Delays and Statements.

c. The development of short stories designed with these matching pairs makes drama scripts in which there are dialogues that can be read with easier interpretation. In the corresponding pair that has been designed allows the reader or actor of the drama to be able to recite the dialogue according to the intonation, the appropriate expression. An example when the demand for information is rejected can be better played even if it is not in the form of sentences negation or renunciation. The nature of ajasensi makes the reader or actor of the script focus more on improvising the dialogue according to the situation or the pairing model matches. The results of this development are in a good category, in accordance with the results of expert tests conducted by native speakers of German (Praktikan) in the Unimed FBS German Language Education Study Program.

d. In the Implementation phase, the results of the drama script can be applied to the lessons in the "Literature" course or the Literature Course at the Unimed FBS German Language Study Program or played at the Oktoberfest event which becomes the annual agenda in the study program so that it is beneficial for students and German literary learners.

e. In the Evaluation Phase, good results were obtained in accordance with the questionnaire distributed to students of the German Language Education study program. The deficiencies and advantages have been revised according to the contents of the questionnaire.

2. The results of this development are in the form of a German drama script which contains dialogues and elements of intrinsic, extrinsic and synopsis interpretation. And as the findings in this study that in a pair of dialogues or conversations can occur more than one pair model corresponds and there is a new place of said actions such as statements, information reinforcement, invitations and delays in rhetorical sentences.

\section{References}

[1]Arsyad, Azhar. 1997. Media Pembelajaran. PT. Raja Grafindo Persada, Jakarta.

[2]Harahap, AB, 2013. Model Pssangan Bersesuaian dalam Struktur Percakapan Bahasa Jerman, Unimed Press, Medan

[3]Isaak Ray, Gudrun and Susan, 2005. Prosa der Gegenwart (A cvollection of Contemporary Prose) . Berlin: Langenscheidt

[4]Rahman dkk. 2013. Strategi dan Desain Pengembangan Sistem Pembelajaran. Prestasi Pustaka, Jakarta

[5]Rusman dkk. 2011. Pembelajaran Berbasis Teknologi Informasi dan Komunikasi. PT. Raja Grafindo Persada, Jakarta

[6]Riyana dkk. 2009. Media Pembelajaran-Hakikat, Pengembangan, Pemanfaatan dan Penilaian.CV Wacana Prima, Bandung

[7]Sanjaya, Wina. 2009. Perencanaan dan Desain Sistem Pembelajaran. Kencana. Jakarta.

[8]Siswanto, Wahyudi, 2008. Pengantar Teori Sastra. Grasindo, Jakarta

[9]Sugiarti, dkk, 2005. Literatur I (Fabel, Lytik, Märchen, Kurzgeschichte und Konkrete Poesie) Zusatsmaterial für den Unterrichslitertur. Yogyakarta: UNY.

[10]https://www.academia.edu/5152425/Makalah_model_ADDIEgesehen, 04 april 2016 21:05.

[11]http://nadisamawa.blogspot.co.id/2013/01/model-pembelajaran-menurut-jerols-e-kemp.html gesehen 4 April 2016 21:10

[12]https://bustangbuhari.wordpress.com/2011/08/25/four-d-model-model pengembangan-perangkatpembelajaran-dari-thiagarajan-dkk/ gesehen 4 April 2016 22:00

[13]http://yandikanjeng.blogspot.co.id/2012/01/penulisan naskah-drama.html, minggu 21 mai 2017, pukul 10.33 
[14]http://albanypoetrm.blogspot.co.id/2010/03/menulis-naskah-drama.html, minggu 21 mai 2017 pukul 10:35

[15]http://staff.uny.ac.id/sites/default/files/tmp/PPM-Menulis\%20Naskah\%20Drama-PLPG.pdf 